Ethos: Jurnal Penelitian dan Pengabdian Masyarakat, Vol 8, No.2, Juni 2020: 300-304

\title{
Pengembangan Kemampuan Diri melalui Test Minat BaKat SiSWa-Siswi SMK
}

\section{${ }^{1}$ Syamsul Rizal, ${ }^{2}$ Munawir, ${ }^{3}$ Upik Sri Sulistyawati, ${ }^{4}$ Muhammad Jamil}

\author{
${ }^{1}$ Program Studi DIII Keuangan dan Perbankan, AKUBANK Nusantara Aceh Timur, \\ ${ }^{2}$ Program Studi DIII Manajemen Informatika, AMIK Indonesia, ${ }^{3}$ ProgramStudi SIManajemen, STIE \\ Sabang Banda Aceh, ${ }^{4}$ Program Studi DIII Keuangan dan Perbankan, AKUBANK Nusantara Aceh Timur \\ email: ${ }^{1}$ Syamsulrizal@akubanknusantara.ac.id, ${ }^{2}$ munawir@amikindonesia.ac.id, ${ }^{3}$ upik@stiesabang.ac.id.
}

\begin{abstract}
Education is one indicator to see the extent of the development and ability of students and students in developing the potential of participants to become reliable, creative, independent Human Resources in accordance with the vision and mission and goals of National Education and can be realized in building a Nation.The aim of this Community Service is to test the participants' abilities by adaptive, creative, innovative and productive and be able to compete in the face of interest and talent tests for Taman Fajar Students in East Aceh, in responding to future challenges according to the potential and talents of the students. participants especially for high school students and equivalents in order to choose the talent in what field the participant in continuing further education in choosing tertiary institutions and what majors will be recommended as many as 87 recommendations according to the test results of the participants of the Department in Higher Education will later come out the results of recommendations 3 options study programs that match the results of interest and aptitude tests of these students. The method used in this interest and aptitude test includes 9 Criteria intensively with the following stages: 1. Visual Reasoning Test 2. Numerical Reasoning Test 3. Verbal Analysis Test 4. Sequencing Reasoning Test 5. Spatial Reasoning Test 6. Three Dimensional Test 7. Systematic Test 8. Vocabulary Test 9. Figural Test Number.The conclusion in this interest and aptitude test can be said that there is a fairly strong correlation (correlation coefficient) between the variable of interest and talent in developing one's ability through interest and aptitude tests to answer future challenges according to his potential. community service activities can be seen from the number of participants who participated very much who are interested can be said to be successful but seen from the results of the test of the participants namely the quality of development of self-efficacy through the learning test test that has been produced, it can be concluded that the objectives of this activity can be achieved and successful.
\end{abstract}

Keywords: Development, self-ability, test of interest, talent

\begin{abstract}
Abstrak. Pendidikan merupakan salah satu indikator untuk melihat sejauh mana perkembangan dan kemampuan Siswa dan siswi dalam mengembangkan potensi peserta agar menjadi Sumber Daya Manusia(SDM) yang handal,kreatif,mandiri sesuai visi dan misi dan tujuan Pendidikan Nasional serta dapat terwujud dalam membangun suatu Bangsa. Tujuan Pengabdian Masyarakat ini adalah untuk menguji kemampuan diri peserta dengan adaptif, kreatif, inovatif dan produktif serta mampu bersaing dalam menghadapi tes minat dan bakat bagi Siswa dan Siswi Taman Fajar di Aceh Timur, dalam menjawab tantangan masa depan sesui potensi dan bakat yang dimiliki oleh para perserta khusunya bagi siswa dan siswi SMU yang sederajat guna Memilih bakat dalam bidang apa peserta tersebut dalam melanjutkan Pendidikan lanjut dalam memilih Perguruan Tinggi serta jurusan apa nantinya yang akan direkomendasi sebanyak 87 rekomendasi sesuai hasil tes para peserta Jurusan di Perguruan Tinggi nantinya keluar hasil rekomendasi 3 Pilihan program study yang sesuai hasil tes minat dan bakat siswa dan siswi tersebut. Metode yang digunakan dalam test minat dan bakat ini meliputi 9 Kriteria secara intensif dengan tahapan sebagai berikut:1.Test Penalaran Visual 2.Test Penalaran
\end{abstract}


Numerik 3.Test analisa Verbal 4.Test Penalaran Urutan 5.Test Penalaran Spasial 6.Test Tiga Dimensi 7.Test Sistematika 8.Test Kosa Kata 9.Test Figural Angka. Kesimpulan dalam tes minat dan bakat ini dapat dikatakan bahwa terdapat hubungan (koefisien korelasi) yang cukup kuat antara variable minat dan bakat dalam pengembangan kemampuan diri melaui tes ninat dan bakat guna menjawab tantangan masa depan sesuai potensi pada dirinya. kegiatan pengabdian kepada masyarakat dilihat dari jumlah peserta yang mengikutinya sangat banyak yang berminat dapat dikatakan berhasil namun dilihat dari hasil test para peserta yaitu kualitas pengembangan kemapuan diri melaui uji tes pembelajaran yang telah dihasilkan, maka dapat disimpulkan bahwa tujuan kegiatan ini dapat tercapai dan berhasil.

Kata Kunci : Pengembangan, Kemampuan diri, tes minat, bakat

\section{Pendahuluan}

Salah satu kondisi yang dihadapi dunia pendidikan tinggi Indonesia saat ini merupakan masalah persaingan yang bersifat lokal, regional dan global. Perguruan Tinggi di Indonesia, baik yang berstatus negeri atau swasta tidak hanya bersaing dengan Perguruan Tinggi lokal tetapi juga berbagai institusi yang merupakan jaringan dari Perguruan Tinggi di tingkat internasional (Nugraha, 2016:191).

Mutu pembelajaran merupakan sesuatu yang dinamis, relevan dengan kebutuhan masyarakat dan pengguna lulusan, berbudaya akademik dalam penyelenggaraan pembelajaran, adanya komitmen kelembagaan dari para pimpinan dan terhadap pengelolaan pembelajaran yang efektif dan produktif, memperhatikan keberlanjutan program, efisiensi serta tingginya akses terhadap perkembangan informasi.

Pembelajaran yang bermutu akan menghasilkan lulusan yang berkualitas pula, sedangkan untuk menghasilkan pembelajaran yang bermutu dibutuhkan guru yang professional, sehingga diharapkan mereka mempunyai kompetensi profesional yang sesuai dengan perubahan dan tantangan jaman, sekaligus untuk menepis adanya anggapan bahwa rendahnya mutu pembelajaran yang berdampak pada rendahnya lulusan. Sehubungan dengan hal itu siswa siswi di SMKN Taman Fajar Aceh Timur berusaha untuk mengetahui kemana kemapuan yang dimiliki oleh dirinya dalam melanjutkan studi diperguruan tinggi nanti dengan jurusan apa yang cocok dan relevan sesuai dengan upgrade ilmu pengetahuan yang dimiliki dalam dirinya.

Pendidikan merupakan salah satu aspek yang sangat penting dalam kehidupan manusia. Namun, kualitas pendidikan di Indonesia sampai saat ini masih belum optimal. Pendidikan merupakan kegiatan mengoptimalkan perkembangan potensi, kecakapan, dan karakteristik pribadi siswa(Silvana, 2016:303).

Tujuan pendidikan adalah mendidik yang khususnya peserta didik SMKN Taman Fajar Aceh Timur untuk menjadi lebih berhasil dalam menghadapi tantangan kedepan yang adaptif, kreatif, inovatif dan produktif serta mampu bersaing dalam mencapi tujuan. Untuk mendukung tujuan tersebut maka dibutuhkan test minat dan bakat yang nantinya dapat melihat kemana kemampuan dirinya dalam memilih jalur pendidikan nantinya Namun dalam kenyataannya masih banyak siswa dan siswi pada SMK yang ada di Provinsi Aceh belum tahu arah dan tujuan yang ingin dicapai khususnya dalam melanjutkan Studi 
lanjut. Berdasar latar belakang tersebut maka identifikasi masalah yang diajukan adalah:

a. Masih terdapat banyak kendala yang menghambat siswa dan siswi SMKN Taman Fajar Aceh Timur dalam memilih Jurusan dalam kuliah yang akan dipilihnya.

b. Masih banyak Siswa dan siswi SMKN Taman Fajar Aceh Timur yang mengalami kesulitan dalam mengetahui kemana jalur pilihan Pendidikannya yang sesuai.

c. Terdapat banyak siswa dan siswi di SMU/MAN/dan SMK se Aceh Timur yang gagal dalam melanjutkan studinya karena tidak sesuai pilihan prodi dengan minat yang di inginkannya.

Untuk Mengetahui bagaimana

Pengembangan Kemampuan diri Melaui Test Minat dan bakat Siswa dan Siswi SMKN Taman Fajar Aceh Timur guna Menjawab Tantangan Masa Depan sesuai Pontensi dan Bakatnya yang dimilikinya.

\section{Metode Penelitian}

Sebelum melakukan test minat dan bakat ini, satu hari sebelum diselenggarakan test minat bakat terlebih dahulu peneliti memberi sosialisasi kepada Siswa dan siswi SMKN Taman Fajar Aceh Timur tentang Tujuan test minat bakat ini adapun test ini dirancang untuk memberikan informasi mengenai bakat dan minat yang relevan dengan keterampilan dan karir serta test ini akan memungkinkan individu untuk mengungkap potensi sebenarnya untuk kemudian peserta didik dapat meningkatkan kelebihan dan mengatasi kelemahan yang ada pada diri peserta didik yang bersangkutan dalam menentukan dan menempuh pendidikan tinggi.

Bentuk materi yang akan di Uji serta dalam pelaksanaan test ini membutuhkan waktu yang lumayan lama lebih kurang memakan waktu 4 Jam atau bekisar 240 Menit, supaya siswa dan siswi SMKN Taman Fajar Aceh Timur. Untuk itu disarankan oleh peneliti, siswa dan Siswi belajar dalam persiapan untuk mengikuti ujian serta pada malam hari untuk tidur lebih awal karena dengan cukup istirahat siswa dan siswi SMKN Taman Fajar Aceh Timur pasti dapat mengerjakan soal-soal yang akan di uji dalam Ujian test minat dan bakat ini dengan bergai soal test.

$$
\text { Adapun langkah-langkah }
$$

kegiatan yang dilakukan dalam test minat dan bakat ini meliputi 9 Kriteria secara intensif dengan tahapan sebagai berikut:
a. Test Penalaran Visual
b. Test Penalaran Numerik
c. Test analisa Verbal
d. Test Penalaran Urutan
e. Test Penalaran Spasial
f. Test Tiga Dimensi
g. Test Sistematika
h. Test Kosa Kata
i. Test Figural Angka

\section{Hasil dan Pembahasan}

Hasil kegiatan Test Minat dan bakat ini secara garis besar mencakup beberapa komponen sebagai berikut:

a. Keberhasilan target jumlah peserta Test.

b. Ketercapaian tujuan Test

c. Ketercapaian target materi yang telah direncanakan

d. Kemampuan peserta dalam penguasaan materi Test

Target peserta pelatihan seperti direncanakan sebelumnya adalah paling tidak setiap sekolah paling kurang 50 Orang siswa dan siswi SMKN Taman Fajar Aceh Timur sesuai dengan jumlah Kelas yang tersedia. Dalam 
pelaksanaannya, kegiatan ini diikuti oleh 100 orang peserta. Dengan demikian dapat dikatakan bahwa target peserta tercapai $100 \%$. Angka tersebut menunjukkan bahwa kegiatan pengabdian kepada masyarakat dilihat dari jumlah peserta yang mengikuti dapat dikatakan berhasil/ sukses.

Ketercapaian tujuan Test Minat dan bakat pengembangan kemampuan diri melaui test minat dan bakat secara umum sudah baik, namun keterbatasan waktu yang disediakan mengakibatkan tidak semua materi tentang pengembangan media pembelajaran dapat disampaikan secara detil. Namun dilihat dari hasil test para peserta yaitu kualitas pengembangan kemapuan diri melaui uji tes pembelajaran yang telah dihasilkan, maka dapat disimpulkan bahwa tujuan kegiatan ini dapat tercapai.

Ketercapaian target test pada kegiatan pengabdian kepada masyarakat ini cukup baik, karena materi yang akan di test telah dapat disampaikan secara keseluruhan. Materi yang telah disampaikan adalah:

a. Virural angka

b. Test kosa kata

c. Test Sistematisasi

d. Test tiga Dimensi

e. Pengenalan Spasial

f. Penalaran Urutan

g. Analisis Verbal

h. Penalaran Nummerik

i. Penalaran Visual

Kemampuan peserta dilihat dari penguasaan materi masih kurang dikarenakan waktu yang singkat dalam penyampaian materi dan kemampuan para peserta yang berbeda-beda. Hal ini disebabkan jumlah materi yang banyak hanya disampaikan dalam waktu sehari sehingga tidak cukup waktu bagi para peserta untuk memahami dan mempraktekkan secara lengkap semua materi yang diberikan.
Secara keseluruhan kegiatan pengembangan kemampuan diri melalui media Test minat dan bakat untuk mengetahuio potensi dirinya ini dapat dikatakan berhasil. Keberhasilan ini selain diukur dari 9 sermbilan komponen di atas, juga dapat dilihat dari kepuasan peserta setelah mengikuti kegiatan. Manfaat yang diperoleh guru adalah dapat menyusun dan mengembangkan media pembelajaran kedepan dengan kualitas yang lebih baik dan diharapkan kualitas tersebut sudah mengikuti standar yang telah di tetapkan oleh Kemendikbud RI.

\section{Kesimpulan dan Saran}

Program pengabdian masyarakat ini dapat diselenggarakan dengan baik dan berjalan dengan lancar sesuai dengan rencana kegiatan yang telah disusun meskipun belum semua peserta didik belum menguasai dengan baik materi yang disampaikan. Kegiatan ini mendapat sambutan sangat baik terbukti dengan keaktifan peserta mengikuti test dengan tidak meninggalkan tempat sebelum waktu pelatihan berakhir.

Berdasarkan evaluasi yang telah dilakukan dapat diajukan beberapa saran sebagai berikut:

a. Waktu pelaksanaan kegiatan pengabdian perlu ditambah agar tujuan kegiatan dapat tercapai sepenuhnya, tetapi dengan konsekuensi penambahan biaya pelaksanaan. Oleh karena itu biaya Pengabdian Kepada Masyarakat sebaiknya tidak sama antara beberapa tim pengusul proposal, mengingat khalayak sasaran yang berbeda pula.

b. Adanya kegiatan lanjutan yang berupa pelatihan sejenis selalu diselenggarakan secara periodik sehinga dapat meningkatkan kemampuan guru dalam 
melaksanakan proses belajar mengajar.

\section{Daftar Pustaka}

Anik Ghufron, 1997. antisipasi Problema Penyiapan dan Peningkatan Guru Memecahkan Masalah Pembelajaran Dalam Konteks Era Global. Cakrawala Pendidikan Edisi Mei 1994. Yogyakarta: IKIP Yogyakarta

Ace Suryadi dan Tilaar.1993. Analisis

Kebijakan Pendidikan Suatu Pengantar. Bandung: PT Remaja Rosdakarya

Depdikbud (1990). Peraturan Pemerintah Republik Indonesia Nomor 30 Tahun 1990. Jakarta. (1993). Kerangka Acuan Pemasyarakatan Kebijakan Pendidikan dan Kebudayaan. Jakarta.

Mulyani A.N.(1996) Peranan Fakultas Keguruan Dan Fakultas Ilmu Pendidikan Bagi Peningkatan Kualitas Profesional Guru Tenaga Kependidikan Lainnya. Makalah seminar temu alumni IKIP Yogyakarta. Mei 1996. Yogyakarta: IKIP Yogyakarta.

Nugraha, N., Nasution, A., \& Amaranti, R. (2016). PENGEMBANGAN MODEL SERVICES QUALITY UNTUK PENINGKATAN KUALITAS LAYANAN AKADEMIK INTERNAL DI PERGURUAN TINGGI. ETHOS: Jurnal Penelitian dan Pengabdian kepada Masyarakat, 191-198.

Seminar Nasional'Merekonstruksi Profesi Guru Memasuki Era Global dan Otonomi" Semarang: UNESA

Silvana, H., \& Wibisono, A. (2016). Penerapan Model Brain Based Learning dalam Pembelajaran di SMAN 10 Bandung. ETHOS: Jurnal Penelitian dan Pengabdian kepada Masyarakat, 303-310.
Suyanto 2003. Sertfikasi Profesi Guru:Jaminan Pengakuan Sekaligus Ancaman.

Tilaar (1991) Manajemen Pendidikan Nasional. Kajian Pendidikan Masa Depan. Bandung: PT Remaja Rosdakarya 